\title{
Crime, Urban Poverty, and Social Science
}

\section{Citation}

Bobo, Lawrence D. 2009. Crime, urban poverty and social science. Du Bois Review: Social Science Research on Race 6(2): 273-278.

\section{Published Version}

doi:10.1017/S1742058X0999021X

\section{Permanent link}

http://nrs.harvard.edu/urn-3:HUL.InstRepos:4724024

\section{Terms of Use}

This article was downloaded from Harvard University's DASH repository, and is made available under the terms and conditions applicable to Other Posted Material, as set forth at http:// nrs.harvard.edu/urn-3:HUL.InstRepos:dash.current.terms-of-use\#LAA

\section{Share Your Story}

The Harvard community has made this article openly available.

Please share how this access benefits you. Submit a story.

Accessibility 


\title{
CRIME, URBAN POVERTY, AND SOCIAL SCIENCE
}

\author{
Lawrence D. Bobo \\ Department of Sociology and of African and African American Studies, \\ Harvard University
}

Todd R. Clear, Imprisoning Communities: How Mass Incarceration Makes Disadvantaged Neighborhoods Worse. New York: Oxford University Press, 2007. 255 pages, ISBN: 978-0-19-538720-9. Paper, \$21.95.

Sudhir Venkatesh, Gang Leader for a Day: A Rogue Sociologist Takes to the Streets. New York: Penguin Press, 2008. 303 pages, ISBN: 978-1-59420150-9. Cloth, \$25.95.

In recent years, sociologists have conducted enormously important research on the intersection of urban poverty, crime, and the racial divide. Quantitative stratification sociologist Bruce Western provides a meticulous tracing of the emergence of mass incarceration, tracking its steady development and identifying how and why-both economically and politically-this trend has fallen so heavily on low-income Black communities (Western 2006). Quantitative stratification sociologist Devah Pager carries out remarkably innovative and compelling field experiments showing the terrible toll incarceration takes on the employment prospects and, therefore, the greater life chances of former felons, particularly those who are Black (Pager 2007). And the combined efforts of quantitative criminologist Chris Uggen and quantitative political sociologist Jeff Manza reveal the extraordinary distortion of our local and national politics that results from the practice of felon disfranchisement (Manza and Uggen, 2006).

To be sure, theoretical sociologists also have made some significant entries regarding the intersection of crime, poverty, and race. David Garland makes a provocative argument about how the challenges of modernity and an array of sociopolitical currents (e.g., the victim's right movement, apprehensions about maintaining order — social control—in an age of extraordinary mobility of people and resources) ushered in the turn to mass incarceration (Garland 2001). Likewise, theorist and ethnographer Loic Wacquant developed a trenchant sociohistorical argument about 
the emergence of a Fourth Stage or regime of racial oppression; namely, from the sequential ashes of slavery, Jim Crow, and then the urban ghetto, now emerges the new carceral state (Wacquant 2001).

I belabor the designations "quantitative sociologist," or "theoretical sociologist," or "ethnographer" to underscore the tiresome nature of what has become a topos among many sociologists: the declaration that only one type of approach-in this instance, qualitative research-can reveal the nuanced meanings of social processes. For me, this topos reaches a frustrating, indeed embarrassing, nadir in a recent first-person narrative account of qualitative research in a low-income public housing project and surrounding neighborhoods in Chicago, written by self-styled "rogue sociologist" Sudhir Venkatesh.

Let's first consider what it means to be a rogue sociologist. Four of the five definitions that the $3^{\text {rd }}$ edition of Webster's New College Dictionary offer for the term "rogue" are deeply unflattering and yet are somehow apt descriptions of Venkatesh's Gang Leader for a Day: A Rogue Sociologist Takes to the Streets. A rogue, according to Webster's, is: 1. An unprincipled person: scoundrel. 2. A playfully mischievous person: scamp. 3. A vicious and solitary animal, as an elephant that has separated itself from its herd. 4. An organism, esp. a plant, that shows an undesirable variation from a standard. 5. Archaic. A wandering vagrant. Both by the strong reputation established by several articles and by his two earlier works (Venkatesh 2000, 2006), as well as in the light of the advance hype, I truly had high expectations of Venkatesh's most recent book. But although he might have intended a work that was "playfully mischievous," the actual product falls much closer to many of the less endearing meanings of the term rogue. To wit, I find Gang Leader to be a major disappointment.

Why such a harsh judgment? First, at different points Venkatesh issues cheap and unsubstantiated assaults on quantitative social research, especially via surveys, urban ethnographies, gang research, and studies of poverty. His oft-repeated sweeping condemnations of entire genres of sociological research (with which he seems almost wholly unacquainted) are, in the main, overtly ideological, a deep disservice to the discipline, and, indeed, unpersuasive, thanks to the complete absence of a real weighing of evidence or direct engagement with the work so maligned.

These flaws might be less distracting in a book that had a more substantial and novel contribution of its own to make. But, second, it is hard to find anything new or substantial in Gang Leader. We have known for some time that those in poor communities and families form many types of networks of support and mutual obligation (Stack 1974, for example). Others have provided more searching analyses of community organizing efforts by the poor (Gregory 1998). We also have far better work on the struggles of low-wage workers (Newman 1999). Sandra Smith (2007) does much more to show how problems of distrust and exploitative relationships undermine interpersonal and communal relations in urban poor communities. Michigan sociologist Alford Young (2004) plumbs with far more sensitivity the range of aspirations, strategies, and identities of young Black men in low income housing projects.

And perhaps most disappointingly, others (for example, Jankowski 1991) have done far more, and have done so more systematically, to reveal the organized nature of gang life than this slim effort. The fraught nature of relations between police and ghetto residents is, similarly, dealt with more thoroughly and rigorously in many other works of research, both quantitative (Hagan, Shedd, and Payne, 2005; Hurwitz and Peffley, 2005; Weitzer and Tuch, 2006) and qualitative (Brunson and Miller, 2006; Brunson 2007).

This long list of topics might lead one to think Gang Leader does at least engage with many important issues normally raised in efforts to gain sociological leverage on 
the dynamics of modern urban poverty. Let's be clear: none of the many topics mentioned above-not one of them-is developed in any analytical detail by Venkatesh. Moreover, the book proceeds as sociologically inspired and grounded but basically very much in the mode of a personal memoir. As such, one does not find, nor is it easily possible to extract, any serious social or theoretical analysis or larger narrative from Gang Leader. Instead, it is a tale, to parody a bit, of "my time spent in the ghetto and the really cool gang leader I met. And, by the way, there was all kind of violence and drug dealing and living and loving and fried food eatin' going on around me while I spent some time in the ghetto."

As a result, sadly, one cannot excuse the choices Venkatesh made as simply the price of accessibility. Others have produced popular social science without reliance upon the inexcusable cheap shots and convenient short cuts that are the building blocks of Gang Leader. To put it more directly: Venkatesh is no Malcolm Gladwell. In a series of intellectually serious and also highly accessible, broadly popular books such as The Tipping Point, Blink, and most recently Outliers, Gladwell has set the modern standard for popularizing social science. Gladwell has shown that careful social scientific thinking and writing need not be left only for a narrow academebound elite to consume or dumbed-down beyond all recognition to be broadly engaging.

Or, to bring the matter even closer to home, Venkatesh falls well short of the sort of standard of accessible but at once powerful and pioneering scholarship of his erstwhile mentor William Julius Wilson. This book is not even a dim shadow of When Work Disappears (Wilson 1996) or even More than fust Race (Wilson 2009), both of which combine broad readability with serious scholarly rigor. Gang Leader, in contrast, is a self-indulgent and opportunistic gesture toward doing social science with a mass appeal.

One might counter that, all these flaws notwithstanding, Venkatesh's book is engagingly written and does offer the occasional insight that borders on the sociological. If the objective is to provide students with a first-person account of life on the hardest of urban America's streets, I'd much rather they read Nathan McCall's powerful autobiography, Makes Me Wanna Holler: A Young Black Man in America (1994), than Venkatesh's admittedly roguish offering.

In Imprisoning Communities, Todd Clear makes a far more serious social scientific contribution. Indeed, Imprisoning Communities is an exemplary combination of accessible writing, careful and systematic weighing of all types of available evidence, and focus on a major social problem. As a result, Clear's work is worthy of broad attention and discussion.

Clear begins with a puzzle. He notes that over the past four decades, we've seen substantial fluctuation in the rate of crime, especially of violent crime. Yet social policy, as well as policing and the criminal justice system, has produced a steady rise in the number of people incarcerated. Is this increased reliance on incarceration making us a safer and more just society?

Clear sounds a very troubling alarm. Not only does he find a basically negligible effect of our new "get tough on crime" regime, he provides compelling evidence of a perversely opposite effect. As he declares early in the book, "imprisonment has grown to the point that it now produces the very social problem on which it feeds. It is the perfect storm" (Clear, p. 4). He meticulously reviews the extant research on the impact of both incapacitation of criminals (time spent in prison rather than among the general population) and deterrence (fear of punishment curbing potential offender involvement in crime) on rates of crime. Incarceration does, in fact, have some impact on crime rates. Yet, in the main, according to Clear: 


\section{Lawrence D. Bobo}

Surprisingly, however, when the body of evidence is considered as a whole, the fairest conclusion is that the effect of imprisonment on crime is not very large and is probably declining as the prison population surges (Clear 2007, p. 45).

Given the steady rise in the number of people incarcerated and the huge investment required to sustain the prison system, these weak effects raise serious questions about our society's reliance on incarceration.

But Clear presses the case even further, arguing that current rates of incarceration have, in fact, become criminogenic. Why, according to Clear, do such high rates of incarceration worsen the crime problem? In part, this happens because the incarceration surge is not spread evenly across the American population but falls with extreme disproportion on particular communities. Low-income Black communities have been affected the most profoundly. As a consequence, in many of these communities young people observe a high percentage of the adult males-their older brothers, uncles, fathers, and grand fathers-spending parts of their lives in prison. The expectation that one will spend some time behind bars becomes routine, ordinary, even reasonable.

Like many other analysts, Clear notes that a large factor in the prison population surge is non-violent drug-related arrests. The "War on Drugs" has contributed to a sense in many poor black communities of unfair and systematic persecution by the criminal justice system. One of the most prominent themes in the qualitative interview data Clear reports is the sense of frustration that police do not respond to real instances of crime and disorder but instead contribute to the criminalization and stigmatization of many young men. The end result is often a deepened questioning of the legitimacy of the criminal justice system (see also Bobo and Thompson, 2006).

More than this, however, Clear argues that racialized mass incarceration weakens the capacity of these communities to be self-regulating social spaces. Many young men in these communities cannot be active parents if they have children, and many do. Even once they return from prison, the stigma of a criminal record severely reduces their employment prospects and further reduces their attractiveness as potential marriage partners for their children's mother.

The end result is that individuals, families, and communities are rendered systematically more vulnerable to future, deeper involvement in crime. By reducing parental capacity to parent children, by further weakening already challenged family structures and resources, and by making already disadvantaged families and communities even less economically viable, incarceration helps to reify a social dynamic that is likely to encourage further involvement in crime.

According to Clear, those who argue for a tough, incarceration-centered anticrime policy must face the realities:

There is good evidence that high rates of incarceration destabilize families, increase rates of delinquency, increase rates of teenage births, foster alienation of youth from pro-social norms, damage frail social networks, and weaken labor markets. It requires a stretch of logic to think that concentrated incarceration contributes to all of these problems, each of which tends to weaken informal social control, but somehow incarceration does not lead to less public safety (Clear 2007, p. 173).

Our current policies and practices are not merely falling short of the goal of seriously curbing crime: they have, in fact, begun to contribute to it. 
Clear calls for a new penal philosophy. He suggests that policy should "set as a central criterion that the justice system contribute to the quality of life in communities - to help make the places where people work, live, and raise their families good places to do these things" (Clear 2007, p. 190). The punitive and retributive model that has driven policy-making must be reconsidered. Although Clear sees some gains to made by focusing on rehabilitation programs and better prisoner re-entry efforts, he does not consider them top priorities. If we want to right the situation, according to Clear, we must incarcerate fewer people, reduce the number of very long sentences, and think carefully about policies that allow for easy technical revocations of probation or parole statuses. He proposes instead an emphasis on community policing strategies. He also reviews in a detailed appendix a potentially promising strategy of community justice programs and centers.

Our society does now face a terrible nexus of urban poverty, crime, and racial bias in the functioning of our criminal justice system (Bobo and Thompson, forthcoming). Sociology as a discipline, spanning the full range of quantitative and qualitative research, can take some real measure of pride in helping to illuminate and problematize a counterproductive policy tendency to call for "getting tough" on crime. Popular discourse and public policy will be further enriched as sociologists insist on bringing our finest ideas and research to bear on matters that should be atop the national agenda.

Corresponding author: Professor Lawrence D. Bobo, Department of Sociology, William James Hall, 33 Kirkland Street, Cambridge, MA 02138. E-mail: bobo@wjh.harvard.edu

\section{REFERENCES}

Bobo, Lawrence D., and Victor Thompson (2006). Unfair by Design: The War on Drugs, Race, and the Legitimacy of the Criminal Justice System. Social Research, 73(2): 445-472.

Bobo, Lawrence D., and Victor Thompson (Forthcoming). Racialized Mass Incarceration: Poverty, Prejudice, and Punishment. In Hazel Rose Markus and Paula Moya (Eds.), Doing Race: 21 Essays for the $21^{\text {st }}$ Century. New York: Norton.

Brunson, Rod K. (2007). 'Police Don't Like Black People': African-American Young Men's Accumulated Police Experiences. Criminology \& Public Policy, 6(1): 71-102.

Brunson, Rod K., and Jody Miller (2006). Young Black Men and Urban Policing in the United States. British fournal of Criminology, 46: 613-640.

Garland, David (2001). The Culture of Control: Crime and Social Order in Contemporary Society. Chicago: University of Chicago Press.

Gladwell, Malcolm (2002). The Tipping Point: How Little Things Can Make a Big Difference. New York: Little, Brown and Company.

Gladwell, Malcolm (2005). Blink: The Power of Thinking without Thinking. New York: Little, Brown and Company.

Gladwell, Malcolm (2008). Outliers: The Story of Success. New York: Little, Brown and Company.

Gregory, Steven (1998). Black Corona: Race and the Politics of Place in an Urban Community. Princeton, NJ: Princeton University Press.

Hagan, John, Carla Shedd, and Monique R. Payne (2005). Race, Ethnicity, and Youth Perceptions of Criminal Injustice. American Sociological Review, 70: 381-407.

Hurwitz, Jon, and Mark Peffley (2005). Explaining the Great Racial Divide: Perceptions of Fairness in the U.S. Criminal Justice System. Fournal of Politics, 67: 762-783.

Jankowski, Martin Sanchez (1991). Islands in the Street: Gangs and American Urban Society. Berkeley, CA: University of California Press.

Manza, Jeff, and Christopher Uggen (2006). Locked Out: Felon Disenfranchisement and American Democracy. New York: Oxford University Press.

McCall, Nathan (1994). Makes Me Wanna Holler: A Young Black Man in America. New York: Vintage. 


\section{Lawrence D. Bobo}

Newman, Katherine S. (1999). No Shame in My Game: The Working Poor in the Inner City. New York: Knopf.

Pager, Devah (2007). Marked: Race, Crime, and Finding Work in an Era of Mass Incarceration. Chicago: University of Chicago Press.

Smith, Sandra Susan (2007). Lone Pursuit: Distrust and Defensive Individualism among the Black Poor. New York: Russell Sage Foundation.

Stack, Carol (1974). All Our Kin: Strategies for Survival in a Black Community. New York: Harper \& Row.

Venkatesh, Sudhir Alladi (2000). American Project: The Rise and Fall of a Modern Ghetto. Cambridge, MA: Harvard University Press.

Venkatesh, Sudhir Alladi (2006). Off the Books: The Underground Economy of the Urban Poor. Cambridge, MA: Harvard University Press.

Wacquant, Loic (2001). Deadly Symbiosis: When Ghetto and Prison Meet and Mesh. Punishment and Society, 3: 95-134.

Weitzer, Ronald, and Steven A. Tuch (2006). Race and Policing in America: Conflict and Reform. New York: Cambridge University Press.

Western, Bruce (2006). Punishment and Inequality in America. New York: Russell Sage Foundation.

Wilson, William Julius (1996). When Work Disappears: The World of the New Urban Poor. New York: Knopf.

Wilson, William Julius (2009). More Than fust Race: Being Black and Poor in the Inner City. New York: Norton.

Young, Alford (2004). The Minds of Marginalized Black Men: Making Sense of Mobility, Opportunity, and Future Life Chances. Princeton, NJ: Princeton University Press. 